\title{
Reactive Transport Modelling of a High-pH Infiltration Test in Concrete
}

\author{
M. Carme Chaparro ${ }^{\mathrm{a}, \mathrm{b}, \mathrm{c}, *}$, Josep M. Soler ${ }^{\mathrm{a}, \mathrm{c}}$, Maarten W. Saaltink ${ }^{\mathrm{b}, \mathrm{c}}$, Urs K. \\ Mäder ${ }^{\mathrm{d}}$ \\ ${ }^{a}$ Institute of Enviromental Assessment and Water Research (IDAEA), CSIC, Jordi \\ Girona 18, 08034 Barcelona, Spain \\ ${ }^{b}$ Department of Civil and Environmental Engineering, Universitat Politècnica de \\ Catalunya (UPC), Jordi Girona 1-3, 08034 Barcelona, Spain \\ ${ }^{c}$ Associated Unit: Hydrogeology Group (UPC-CSIC) \\ ${ }^{d}$ Rock-Water Interaction, Institute of Geological Sciences, University of Bern, \\ Baltzerstrasse 1-3, CH-3012 Bern, Switzerland.
}

\begin{abstract}
A laboratory-scale tracer test was carried out to characterize the transport properties of concrete from the Radioactive Waste Disposal Facility at El Cabril (Spain). A hyperalkaline solution (K-Ca-OH, $\mathrm{pH}=13.2$ ) was injected into a concrete sample under a high entry pressure in order to perform the experiment within a reasonable time span, obtaining a decrease of permeability by a factor of 1000 . The concentrations of the tracers, major elements $\left(\mathrm{Ca}^{2+}, \mathrm{SO}_{4}^{2-}, \mathrm{K}^{+}\right.$and $\left.\mathrm{Na}^{+}\right)$and $\mathrm{pH}$ were measured at the outlet of the concrete sample. A reactive transport model was built based on a double porosity conceptual model, which considers diffusion between a mobile zone, where water can flow, and an immobile zone without any advective transport. The numerical model assumed that all reactions took place in the immobile zone. The cement paste consists of C-S-H gel, portlandite, ettringite, calcite and gypsum, together with residual alite and belite. Two different models were compared, one with portlandite in equilibrium (high initial surface area) and another one with portlandite reaction controlled by kinetics (low initial surface area). Overall the results show dissolution of alite, belite, gypsum,
\end{abstract}

\footnotetext{
*Corresponding author. Present address: c/Jordi Girona 1-3, Universitat Politècnica de Catalunya (UPC), Building D2, Office 004/1, 08034 Barcelona, Spain. Tel.: +34 934011858.

Email address: m.carme.chaparro@upc.edu (M. Carme Chaparro)
} 
quartz, C-S-H gel and ettringite and precipitation of portlandite and calcite. Permeability could have decreased due to mineral precipitation.

Keywords: reactive transport, double-porosity, concrete, numerical model

\section{Introduction}

Cementitious materials are used as engineered barriers in order to store radioactive waste. For example, concrete is used to store low- and intermediatelevel radioactive waste at El Cabril (Spain), which is the motivation of this work. The problem at El Cabril is that there is a flow of water inside the concrete cells used to store the radioactive waste (Chaparro and Saaltink, 2016). It is important to know the transport properties of concrete, in order to understand the processes that take place inside the concrete cells. For this reason, in a previous work, a laboratory-scale tracer test in a concrete sample was performed, and numerical models taking into account the matrix diffusion conceptual model were developed (Chaparro et al., 2016). In that experiment, hyperalkaline solution (K-Ca-OH, $\mathrm{pH}$ 13.2) was injected into concrete. In the test, the permeability decreased by a factor of 1000 (Figure $1)$. This could be due to mineral precipitation. Hence, in this work, a reactive transport model has been developed to study the changes in mineralogy that may have occurred during the test. In the literature, few studies have reported infiltration tests in concrete. One of the studies was reported by Chapwanya et al. (2009), who modelled re-wetting experiments in concrete. They consist of placing dry concrete samples in a liquid bath and observing the progress of the wetting front. Both water and isopropanol were used as infiltration solutions. However, reactions were produced when water was used. Residual alite and belite dissolved, and as a consequence C-S-H gel precipitated reducing the porosity. Further studies have been published on the geochemical interaction of the cement pore water with granite or clay materials (Pfingsten et al., 2006; De Windt et al., 2008; Kosakowski and Berner, 2013; Soler, 2013, 2016). Reactive transport models in hardened cement were also reported by Soler et al. (2011) and Soler (2012). They studied the changes in mineralogy and porosity generated by the interaction between water and a cementitious grout by means of numerical models. None of them applied reactive transport in a double porosity model together under advective flow through the concrete. The objective of this work is to study the reactive transport in concrete taking into account the double porosity 
conceptual model.

\section{Materials and Methods}

As explained by Chaparro et al. (2016), the concrete used was manufactured at El Cabril by ENRESA (Spanish Nuclear Waste Management Company) following the same procedure that is used to make the concrete for storing the radioactive waste. Its intrinsic permeability was between $8 \times 10^{-19}$ and $4.5 \times 10^{-18} \mathrm{~m}^{2}$ (hydraulic conductivity between $4.8 \times 10^{-14}$ and $2.16 \times 10^{-12} \mathrm{~m} / \mathrm{s}$ ) and the $\mathrm{w} / \mathrm{c}$ ratio was 0.44 . Table 1 shows the composition

of the concrete and Table 2 gives the composition of the cement used for preparing the concrete.

Table 1: Concrete composition. Minimum and maximum sizes ( $\mathrm{mm}$ ) of the aggregate or sand are given within parenthesis (Chaparro et al., 2016).

\begin{tabular}{ll}
\hline Component & Quantity \\
\hline Aggregates (4/16) & $1023 \mathrm{~kg} / \mathrm{m}^{3}$ \\
Sand $(0 / 4)$ & $434 \mathrm{~kg} / \mathrm{m}^{3}$ \\
Sand $(0 / 2)$ & $403 \mathrm{~kg} / \mathrm{m}^{3}$ \\
Ordinary Portland Cement I-42.5 R/SR & $400 \mathrm{~kg} / \mathrm{m}^{3}$ \\
Rheobuild 1222 additive (superplasticizer) & $6.5 \mathrm{~kg} / \mathrm{m}^{3}$ \\
Water & $175 \mathrm{~L} / \mathrm{m}^{3}$ \\
\hline
\end{tabular}

The experiment is explained in detail by Chaparro et al. (2016). The diameter of the concrete sample was $5.5 \mathrm{~cm}$ and its length $5.5 \mathrm{~cm}$. The lateral sides of the sample were waterproofed so as to avoid infiltration of water through those sides. A device was used that allows injecting solution with a high infiltration pressure of 20 bars. Confining pressure was 50 bars. The test consisted of injecting a high $\mathrm{pH}$ solution with tracers (lithium, bromide and deuterium) at the bottom of the sample using a pulse injection. Afterwards, the same solution, but without tracers, was injected until the end of the test. The infiltration solutions were composed of distilled water with $10.6 \mathrm{~g} / \mathrm{L}$ of $\mathrm{KOH}$ and $0.1 \mathrm{~g} / \mathrm{L}$ of $\mathrm{Ca}(\mathrm{OH})_{2}$ giving a $\mathrm{pH}$ of 13.2 . The outlet solution at 
Table 2: Cement composition (Ordinary Portland Cement I-42.5 R/SR).

\begin{tabular}{ll}
\hline Component & Quantity $(\mathrm{kg} / \mathrm{kg})$ \\
\hline $\mathrm{SiO}_{2}$ & $19.2 \times 10^{-2}$ \\
$\mathrm{Al}_{2} \mathrm{O}_{3}$ & $1.2 \times 10^{-2}$ \\
$\mathrm{Fe}_{2} \mathrm{O}_{3}$ & $4.5 \times 10^{-2}$ \\
$\mathrm{CaO}$ & $66.1 \times 10^{-2}$ \\
$\mathrm{MgO}$ & $1.2 \times 10^{-2}$ \\
$\mathrm{SO}_{3}$ & $3.1 \times 10^{-2}$ \\
$\mathrm{~K}_{2} \mathrm{O}$ & $3.3 \times 10^{-3}$ \\
$\mathrm{CaCO}_{3}$ & $5 \times 10^{-2}$ \\
$\mathrm{Total}^{2}$ & 1.01 \\
\hline
\end{tabular}

the top of the sample was collected by syringes. The measured components were the tracers (lithium, bromide and deuterium), $\mathrm{Ca}, \mathrm{SO}_{4}, \mathrm{~K}, \mathrm{Na}$ and $\mathrm{pH}$. Data obtained are compared with the results of the numerical model (Figure 3). During the experiment, the hydraulic conductivity decreased with time by a factor of 1000, which could be due to mineral precipitation. Figure 1 shows the evolution of the hydraulic conductivity during the test.

\section{Numerical Model}

To interpret the experiment and quantify processes and chemical reactions a reactive transport model was developed. A double porosity model had to be implemented by Chaparro et al. (2016) to interpret the transport of conservative tracers in this same experiment. This double porosity model is now applied to the reactive transport modelling of the experiment (Figure 2). The domain consists of a mobile zone representing the well connected pores, where water can flow and solutes are transported by advection, dispersion and diffusion, and an immobile zone representing the matrix with only diffusion. The domain is represented by a finite element mesh of 561 nodes and 560 elements. Nodes connected by 1D elements in the $y$ direction represent the 


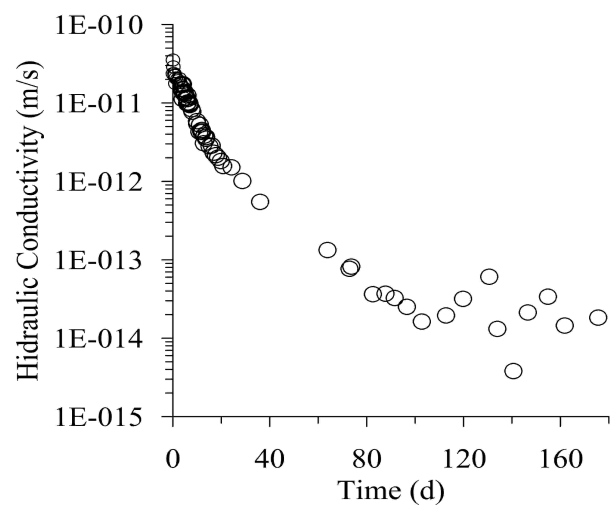

Figure 1: Evolution of the hydraulic conductivity. Calculated from data in Chaparro et al. (2016).

mobile zone. From each of these nodes a string of nodes and $1 \mathrm{D}$ elements in the $x$ direction represent the immobile zone. The length of the mobile zone is equal to the length of the sample $(5.5 \mathrm{~cm})$. The tracer test cannot estimate both the length $\left(\mathrm{L}_{c}\right)$ and the diffusion coefficient $\left(\mathrm{D}_{i m}\right)$ of the immobile zone. Only a characteristic time for diffusion $\left(t_{c}=L_{c}^{2} / D_{i m}\right)$ can be used, which is 40.7 days. The porosities of the mobile zone and immobile zone are 0.029 and 0.141 , respectively (Chaparro et al., 2016). We used measured flow rates as prescribed flow boundary condition. This implicitly takes into account the change in permeability and its effect on flow. The simulations were carried out using the reactive transport code Retraso-CodeBright (Saaltink et al., 2004).

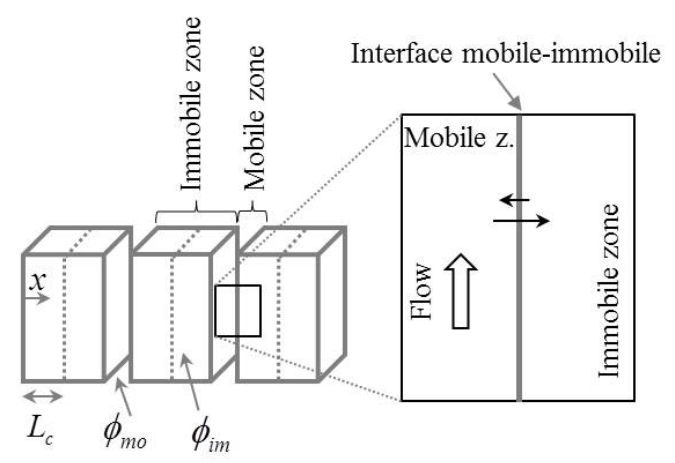

Figure 2: Conceptual model (Chaparro et al., 2016). 


\subsection{Mineral Phases}

Table 3 shows the phases taken into account by the numerical model. These were the phases detected by X-ray diffraction plus C-S-H gel. The cement paste is composed of alite and belite, which are the residual clinker phases, C-S-H gel, gypsum, calcite, portlandite and ettringite. The model assumes that aggregates are composed only of quartz, because it is the main component. Monosulphate or other minor phases were not considered because they were not found by X-ray diffraction. The C-S-H gel is not a pure phase, but a solid solution with varying $\mathrm{Ca} / \mathrm{Si}$ ratios. This is modelled by assuming 19 pure minerals with $\mathrm{Ca} / \mathrm{Si}$ ratios ranging from 0.83 to 1.67 as was done by Trapote-Barreira et al. (2014). We used the C-S-H-1667 gel $(\mathrm{Ca} / \mathrm{Si}=1.667)$, as primary phase and the others as secondary phases. We did not consider minerals in the mobile zone, all of them are located in the immobile zone, which represents the matrix. At first, it was assumed that minerals were present in the mobile zone and the initial water composition was the same for both the mobile and immobile zones. However, it was not possible to reproduce the chemical composition of the early breakthrough using this approach. A different water composition, consistent with the measured early breakthrough had to be defined for the mobile zone. And to avoid equilibrium of this water with respect to the cement minerals, these minerals were excluded from the mobile zone. In the immobile zone, the initial reactive areas of calcite, ettringite, portlandite and C-S-H gel are from Trapote-Barreira (2015), who used a mortar prepared with the same cement. The ones for alite, belite, gypsum and quartz were calibrated by fitting the model results to the experimental data. The volumetric fractions of the phases (Table 3) were calculated from the cement and concrete composition.

\subsection{Thermodynamic Data}

Table 4 shows the thermodynamic data used in the numerical model, at $25{ }^{\circ} \mathrm{C}$. The clinker phases alite and belite, are assumed irreversible. Data for gypsum, calcite and quartz were taken from the EQ3/6 database (Wolery et al., 1990). The data of the discretized C-S-H gel were taken from Trapote-Barreira et al. (2014), who used the solid solution model reported by Kulik and Kersten (2001). The thermodynamic data of portlandite was taken from Hummel et al. (2002) and the one for ettringite is from Lothenbach et al. (2008). Also aqueous complexation reactions were included (Table $5)$. These were selected by means of a speciation calculation with PHREEQC 
Table 3: Phases used in the numerical model for the mobile and immobile zones.

\begin{tabular}{|c|c|c|c|c|c|}
\hline Phase & $\begin{array}{l}\text { Mobile } \\
\mathrm{V}_{\text {phase }} / \mathrm{Vt}\end{array}$ & $\begin{array}{l}\sigma_{\mathrm{mo}} \\
\left(\mathrm{m}^{2} \mathrm{~m}^{-3}\right)\end{array}$ & $\begin{array}{l}\text { Immobile } \\
\mathrm{V}_{\text {phase }} / \mathrm{Vt}\end{array}$ & $\begin{array}{l}\sigma_{\mathrm{im}} \\
\left(\mathrm{m}^{2} \mathrm{~m}^{-3}\right)\end{array}$ & $\begin{array}{l}\text { Total } \\
\mathrm{V}_{\text {phase }} / \mathrm{Vt}\end{array}$ \\
\hline Alite & 0 & 0 & $5.63 \times 10^{-3}$ & $0.7^{(\mathrm{a})}$ & $5.63 \times 10^{-3}$ \\
\hline Belite & 0 & 0 & $4.01 \times 10^{-3}$ & $0.7^{\text {(a) }}$ & $4.01 \times 10^{-3}$ \\
\hline Gypsum & 0 & 0 & $1.17 \times 10^{-3}$ & $0.01^{\text {(a) }}$ & $1.17 \times 10^{-3}$ \\
\hline Calcite & 0 & 0 & $6.12 \times 10^{-3}$ & $5073^{(\mathrm{b})}$ & $6.12 \times 10^{-3}$ \\
\hline Quartz & 0 & 0 & $0.63^{*}$ & $10^{(\mathrm{a})}$ & $0.63^{*}$ \\
\hline Ettringite & 0 & 0 & $3.21 \times 10^{-2}$ & $116007^{(b)}$ & $3.21 \times 10^{-2}$ \\
\hline Portlandite & 0 & 0 & $6.92 \times 10^{-2}$ & $8270^{(b)}$ & $6.92 \times 10^{-2}$ \\
\hline C-S-H-1667 & 0 & 0 & $7.97 \times 10^{-2}$ & 1649468 (b) & $7.97 \times 10^{-2}$ \\
\hline Porosity & 0.029 & & 0.141 & & 0.17 \\
\hline Total & 0.029 & & 0.971 & & 1 \\
\hline
\end{tabular}

* Volume of aggregates with respect to the total volume of the sample. a) calibrated, b) Trapote-Barreira (2015). 
(Parkhurst and Appelo, 1999), the thermodynamic data was taken from EQ3/6 database (Wolery et al., 1990).

Table 4: Equilibrium constants taken into account in the numerical model. Only the end-members are shown in the C-S-H gel solid solution. Reactions are written as the dissociation of $1 \mathrm{ml}$ of aqueous species in terms of the primary species $\mathrm{Ca}^{2+}, \mathrm{SiO}_{2}(\mathrm{aq})$, $\mathrm{Al}(\mathrm{OH})_{4}^{-}, \mathrm{H}^{+}, \mathrm{SO}_{4}^{2-}$ and $\mathrm{HCO}_{3}^{-}$, a) EQ3/6 database (Wolery et al., 1990), b) TrapoteBarreira et al. (2014), c) Hummel et al. (2002), d) Lothenbach et al. (2008).

\begin{tabular}{lll}
\hline Solid & Formula & $\log \mathrm{K}_{e q}$ \\
\hline Alite & $\mathrm{C}_{3} \mathrm{~S}\left(3 \mathrm{CaO} \cdot \mathrm{SiO}_{2}\right)$ & irreversible \\
Belite & $\mathrm{C}_{2} \mathrm{~S}\left(2 \mathrm{CaO} \cdot \mathrm{SiO}_{2}\right)$ & irreversible \\
Gypsum & $\mathrm{CaSO}_{4} \cdot 2 \mathrm{H}_{2} \mathrm{O}$ & $-4.48^{\text {(a) }}$ \\
Calcite & $\mathrm{CaCO}_{3}$ & $1.84^{\text {(a) }}$ \\
Quartz & $\mathrm{SiO}_{2}$ & $-3.99^{\text {(a) }}$ \\
C-S-H-083 & $\mathrm{C}-\mathrm{S}-\mathrm{H} \mathrm{ss}, \mathrm{Ca} / \mathrm{Si}=0.83$ & $11.15^{\text {(b) }}$ \\
C-S-H-1667 & $\mathrm{C}-\mathrm{S}-\mathrm{H} \mathrm{ss}, \mathrm{Ca} / \mathrm{Si}=1.667$ & $29.13^{\text {(b) }}$ \\
Portlandite & $\mathrm{Ca}(\mathrm{OH})_{2}$ & $22.80^{\text {(c) }}$ \\
Ettringite & $\mathrm{Ca}_{6} \mathrm{Al}_{2}\left(\mathrm{SO}_{2}\right)_{3}(\mathrm{OH})_{12} 26 \mathrm{H}_{2} \mathrm{O}$ & $-44.90^{\text {(d) }}$ \\
\hline
\end{tabular}

\subsection{Kinetic Rate Laws}

A kinetic approach is used for the dissolution-precipitation of mineral phases, although sometimes the reaction is fast enough to be practically at equilibrium. The kinetic rate constants used in the numerical model are shown in Table 6. Two types of rate law have been considered. We used irreversible rates for alite and belite (Equation 1). The rates for the other minerals correspond to Equation 2. The kinetic rate constants (k) for alite and belite have been taken from Savage et al. (2011). Data for the other minerals are from Trapote-Barreira et al. (2014).

$$
\begin{gathered}
r=k \sigma \\
r=k \sigma a_{\mathrm{H}_{+}}^{\mathrm{n}}(1-\Omega)
\end{gathered}
$$


Table 5: Secondary species with their equilibrium constants $\left(\log K_{\text {eq }}\right)$ taken into account in the numerical model (EQ3/6 database, Wolery et al. (1990)). Reactions are written as the dissolution of $1 \mathrm{~mol}$ of mineral in terms of the primary species $\mathrm{Ca}^{2+}, \mathrm{SiO}_{2}(\mathrm{aq})$, $\mathrm{Al}(\mathrm{OH})_{4}^{-}, \mathrm{H}^{+}, \mathrm{SO}_{4}^{2-}$ and $\left.\mathrm{HCO}_{3}^{-}\right)$.

\begin{tabular}{|c|c|c|c|}
\hline Formula & $\log K_{e q}$ & Formula & $\log K_{e q}$ \\
\hline $\mathrm{Al}(\mathrm{OH})_{6} \mathrm{SiO}^{-}$ & -3.60 & $\mathrm{CaHCO}_{3}^{+}$ & -1.04 \\
\hline $\mathrm{Al}(\mathrm{OH})_{3}(\mathrm{aq})$ & 16.15 & $\mathrm{CO}_{2}(\mathrm{aq})$ & -6.34 \\
\hline $\mathrm{Al}(\mathrm{OH})_{2}^{+}$ & 10.09 & $\mathrm{KOH}(\mathrm{aq})$ & 14.46 \\
\hline $\mathrm{AlOH}^{2+}$ & 5.01 & $\mathrm{KSO}_{4}^{-}$ & -0.87 \\
\hline $\mathrm{AlSiO}(\mathrm{OH})_{3}^{2+}$ & -7.40 & $\mathrm{NaCO}_{3}^{-}$ & -0.51 \\
\hline $\mathrm{AlSO}_{4}^{+}$ & -3.01 & $\mathrm{NaOH}(\mathrm{aq})$ & 14.18 \\
\hline $\mathrm{AlSO}_{4}^{-2}$ & -4.9 & $\mathrm{NaSO}_{4}^{-}$ & -0.82 \\
\hline $\mathrm{CaCO}_{3}(\mathrm{aq})$ & 7.00 & $\mathrm{NaHCO}_{3}(\mathrm{aq})$ & -0.15 \\
\hline $\mathrm{CaOH}^{+}$ & 12.85 & $\mathrm{HSO}_{4}^{-}$ & -1.97 \\
\hline $\mathrm{CaSO}_{4}(\mathrm{aq})$ & -2.11 & $\mathrm{SiO}(\mathrm{OH})_{3}^{-}$ & 9.80 \\
\hline $\mathrm{CaSiO}_{2}(\mathrm{OH})_{2}$ & -4.60 & $\mathrm{SiO}_{2}(\mathrm{OH})_{2}^{2-}$ & 23.13 \\
\hline $\mathrm{CaSiO}(\mathrm{OH})_{3}^{+}$ & -1.20 & & \\
\hline
\end{tabular}


$r$ is the mineral dissolution rate $\left(\mathrm{mol} \mathrm{m} \mathrm{m}^{-2} \mathrm{~s}^{-1}\right), k$ is the kinetic rate constant $\left(\mathrm{mol} \mathrm{m} \mathrm{m}^{-2} \mathrm{~s}^{-1}\right), \sigma$ is the surface area $\left(\mathrm{m}^{2} \mathrm{~m}^{-3}\right), a_{\mathrm{H}^{+}}$is the activity of $H^{+}, n$ is a coefficient determined experimentally and $\Omega$ is the ratio between the ion activity product and the equilibrium constant.

Table 6: Kinetic rate constants ( $\log \mathrm{k})$ used in the numerical model. They are from a) Savage et al. (2011) or b) Trapote-Barreira et al. (2014).

\begin{tabular}{lll}
\hline Solid & $\log \mathrm{k}^{\left(\mathrm{mol} \mathrm{m} \mathrm{m}^{-2} \mathrm{~s}^{-1}\right)} \mathrm{n}$ \\
\hline Alite & $-5.5^{(\mathrm{a})}$ & - \\
Belite & $-6.5^{(\mathrm{a})}$ & - \\
Gypsum & $-6^{(\mathrm{b})}$ & 0 \\
Calcite & $5.81^{(\mathrm{b})}$ & 0 \\
Quartz & $-14.9^{(\mathrm{b})}$ & -0.4 \\
C-S-H-083 & $-10.99^{(\mathrm{b})}$ & 0 \\
C-S-H-1667 & $-8.40^{(\mathrm{b})}$ & 0 \\
Portlandite & $-5.14^{(\mathrm{b})}$ & 0 \\
Ettringite & $-8.80^{(\mathrm{b})}$ & 0 \\
\hline
\end{tabular}

\subsection{Solution Composition}

The initial compositions of the pore water and the infiltration water are given in Table 7 . The pore waters for the mobile and immobile zones are different. In the immobile zone the water is assumed to be electrically neutral and in equilibrium with C-S-H-1667, ettringite, calcite and portlandite. The total aqueous concentrations of $\mathrm{Na}, \mathrm{K}$ and $\mathrm{SO}_{4}$ are equal to the measured values (early solution breakthrough in the experiment). However, the pore water in the mobile zone is not in equilibrium with the cement phases. An explanation could be that the water of the mobile zone had suffered some alteration due to the manipulation of the sample, without having enough time to equilibrate through diffusion with the water of the immobile zone, because this is a slow process $\left(t_{c}=40.7\right.$ days $)$. Total concentrations of $\mathrm{Ca}, \mathrm{Si}$ and $\mathrm{Al}$ were adjusted to fit the model to the first part of the measured $\mathrm{Ca}$ breakthrough curve (from 0 to 5 day, Figure 3 ). Na and $\mathrm{CO}_{3}$ concentrations 
were calculated assuming charge balance and equilibrium with calcite. We used the measured values (early breakthrough) for $\mathrm{pH}$ and $\mathrm{K}$ and $\mathrm{SO}_{4}$ concentrations. The infiltration water contains $\mathrm{Ca}$ and $\mathrm{K}$, which were measured. $\mathrm{CO}_{3}$ concentration and $\mathrm{pH}$ were calculated assuming equilibrium with calcite and zero charge balance. Concentrations of other components are effectively zero.

\section{Results and Discussion}

\subsection{Solution Composition}

The evolution of the measured concentrations at the outlet of the experiment are compared with the model results in Figure 3. Only $\mathrm{Ca}, \mathrm{SO}_{4}, \mathrm{~K}, \mathrm{Na}$ and $\mathrm{pH}$ were measured. There are no experimental data for $\mathrm{Si}, \mathrm{Al}$ and $\mathrm{CO}_{3}$. Two models are compared. First, we made a model with an initial surface area of portlandite $(\sigma)$ of $8270 \mathrm{~m}^{2} \mathrm{~m}^{-3}$, where the solution is always practically in equilibrium with portlandite. However, this model did not give good fits, in order to get better fits, we made another model with an initial surface area of $0.0827 \mathrm{~m}^{2} \mathrm{~m}^{-3}$, where portlandite precipitation is controlled by kinetics. Both models give identical results for $\mathrm{K}$ and $\mathrm{Na}$ (because these components are conservative) and have similar results for $\mathrm{CO}_{3}$ and $\mathrm{pH}$, obtaining good fits. Nonetheless, they differ for the other components $\left(\mathrm{Ca}, \mathrm{Si}, \mathrm{SO}_{4}\right.$ and $\mathrm{Al})$. The model where portlandite is in equilibrium $\left(\sigma=8270 \mathrm{~m}^{2} \mathrm{~m}^{-3}\right)$ does not fit well measured Ca. The precipitation-dissolution at equilibrium fixes the $\mathrm{Ca}$ concentrations at $2.5 \times 10^{-3} \mathrm{~mol} / \mathrm{L}$, whereas measured data indicate an undersaturation with respect to portlandite at the beginning of the test, and a supersaturation afterwards. This is reflected better by the model with $\sigma=0.0827 \mathrm{~m}^{2} \mathrm{~m}^{-3}$. We fitted the first part of the Ca breakthrough curve (from 0 to 5 day) by calibrating the initial $\mathrm{Ca}, \mathrm{Si}$ and $\mathrm{Al}$ concentrations of the water of the mobile zone (Table 7 ). The part of the breakthrough curve where $\mathrm{Ca}$ is oversaturated with respect to portlandite (from day 5 on) was fitted by calibrating the surface areas of alite, belite and portlandite. We used the kinetic rate constants from the literature and we calibrated the surface area because it is subject to larger uncertainties than the rate constant. The slow kinetics allows the chemical composition to deviate more from equilibrium with respect to portlandite. The dissolution of alite and belite provide the Ca driving portlandite precipitation. Similar results for Si were obtained for both models, but the concentration of Si increases more rapidly at the beginning in the model where $\sigma$ is $0.0827 \mathrm{~m}^{2} \mathrm{~m}^{-3}$. The slower increase in Ca 


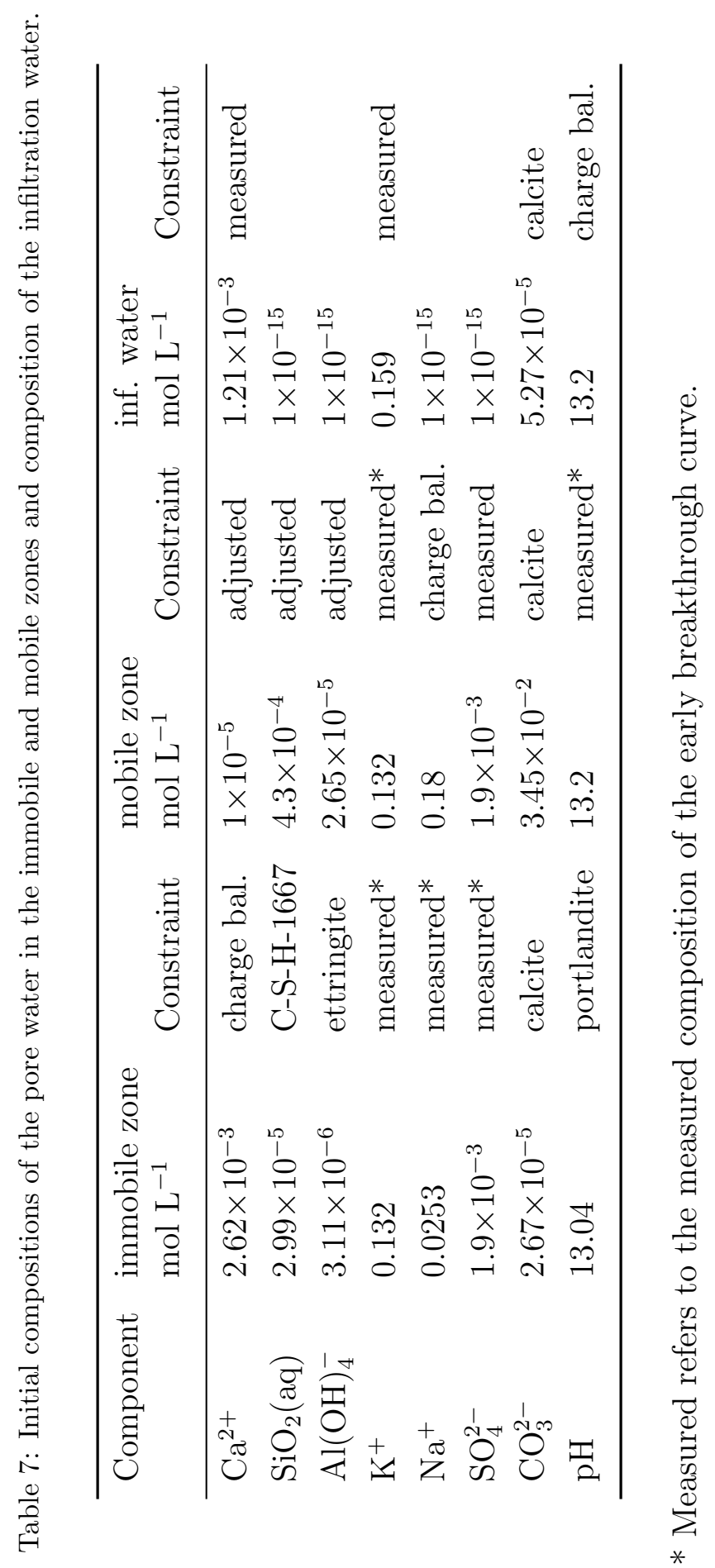


concentration allows larger Si concentration due to equilibrium with respect to $\mathrm{C}-\mathrm{S}-\mathrm{H}$. Likewise, the concentrations of $\mathrm{SO}_{4}$ and $\mathrm{Al}$ increase rapidly at the beginning in the model with $\sigma=0.0827 \mathrm{~m}^{2} \mathrm{~m}^{-3}$ (ettringite equilibrium). Both models have a good fit for $\mathrm{SO}_{4}$.

Figures 4 and 5 show concentrations versus dimensionless distance into the immobile zone at the inlet $(y=0 \mathrm{~cm})$ and outlet $(y=5.5 \mathrm{~cm})$ of the sample and for two different times (at 0.2 and 14 days). In the $x$ axis, 0 represents the mobile zone and the immobile zone starts from there. Figure 4 displays the results of the model with $\sigma=8270 \mathrm{~m}^{2} \mathrm{~m}^{-3}$ and Figure 5 the ones with a $\sigma=0.0827 \mathrm{~m}^{2} \mathrm{~m}^{-3}$. A similar concentration of $\mathrm{Ca}$ is obtained for the whole domain and all times when portlandite is in equilibrium $\left(\sigma=8270 \mathrm{~m}^{2} \mathrm{~m}^{-3}\right)$. However, when portlandite dissolution is controlled by kinetics $(\sigma=0.0827$ $\mathrm{m}^{2} \mathrm{~m}^{-3}$ ), the concentration of Ca increases with time and also throughout the immobile zone, due to the dissolution of the clinker phases (alite and belite). Both models have identical results for $\mathrm{K}$ and $\mathrm{Na}$ as these are conservative components. $\mathrm{K}$ increases slightly with time because the infiltration water has a higher concentration of $\mathrm{K}$ than the pore water. On the other hand, $\mathrm{Na}$ decreases with time because the infiltration water does not contain Na. For all the other components both models give similar results.

\subsection{Mineral Variation}

The variation of volumetric fraction of minerals versus dimensionless length (of immobile zone) are displayed in Figures 6 and 7. Like in the previous subsection, they compare the mineral variation at the inlet and outlet of the sample $(y=0 \mathrm{~cm}$ and $y=5.5 \mathrm{~cm}$ respectively) and two different times (0.2 and 14 days). Figure 6 shows the model results when portlandite is in equilibrium $\left(\sigma=8270 \mathrm{~m}^{2} \mathrm{~m}^{-3}\right)$ and Figure 7 when the portlandite is controlled by kinetics $\left(\sigma=0.0827 \mathrm{~m}^{2} \mathrm{~m}^{-3}\right)$. Both models show a dissolution of alite and belite that is constant in the whole domain, because of the assumed irreversible rate laws (Equation 1). Dissolution of clinker phases causes the precipitation of portlandite and C-S-H gel. Gypsum and quartz show also minor dissolution in both models in a similar way as the clinker phases. On the other hand, calcite precipitates at the beginning of the immobile zone (near $x=0$ ). Ettringite is dissolving near the mobile zone. Both models show similar results for C-S-H gel, which is dissolving near the mobile zone, while there is little precipitation in the immobile zone. The lack of $\mathrm{SO}_{4}, \mathrm{Al}$ and $\mathrm{Si}$ in the infiltration water (Table 7) could have caused $\mathrm{C}-\mathrm{S}-\mathrm{H}$ and ettringite dissolution, increasing the concentration of $\mathrm{SO}_{4}, \mathrm{Al}$ and $\mathrm{Si}$ at the beginning 

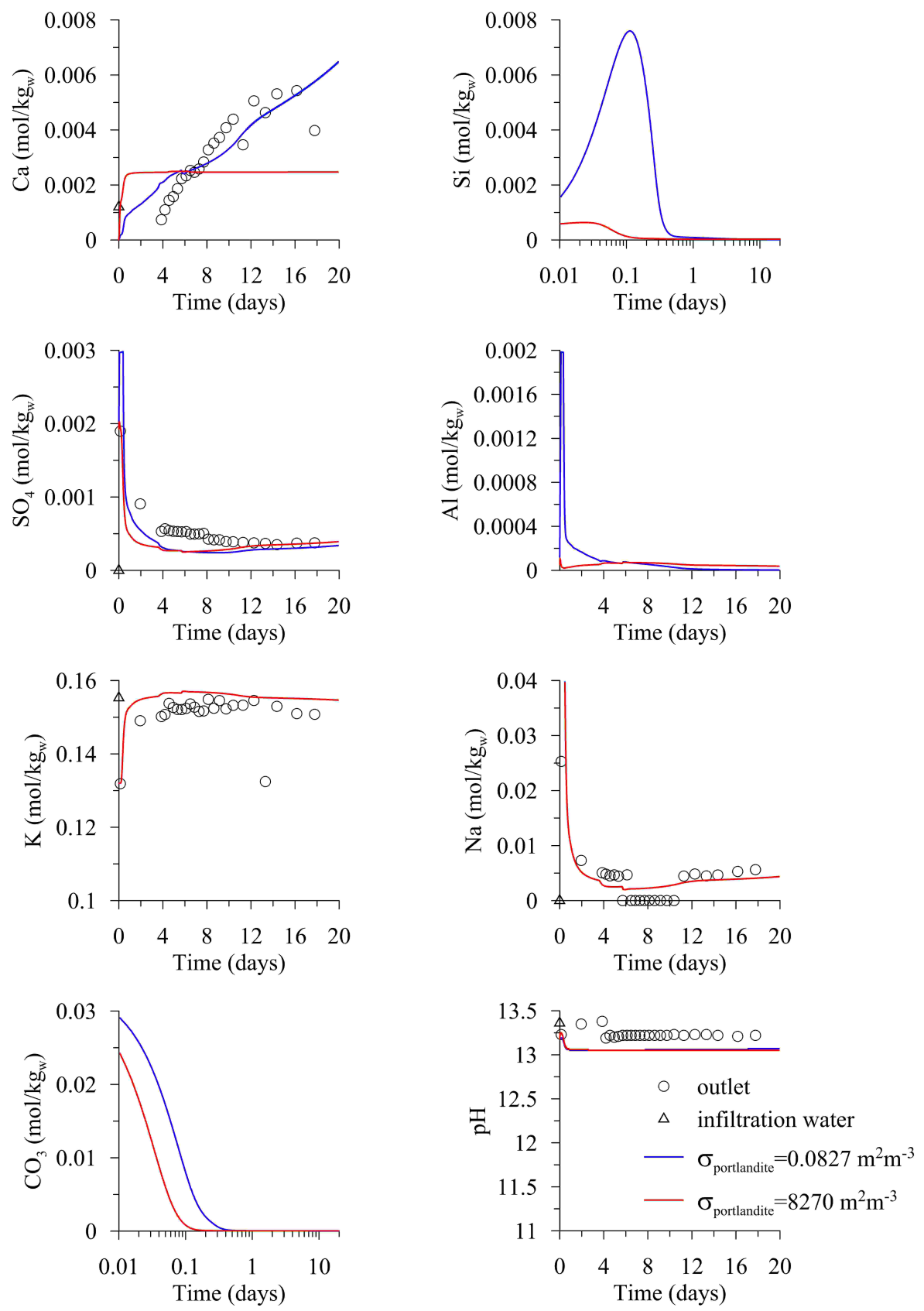

Figure 3: Evolution of the measured concentration (points) compared with the ones calculated by the numerical model (lines). The triangles represent the concentration of the infiltration water. No data were available for $\mathrm{Si}, \mathrm{Al}$ and $\mathrm{CO}_{3}$. Si plot in logarithmic scale to see better the changes in concentration 

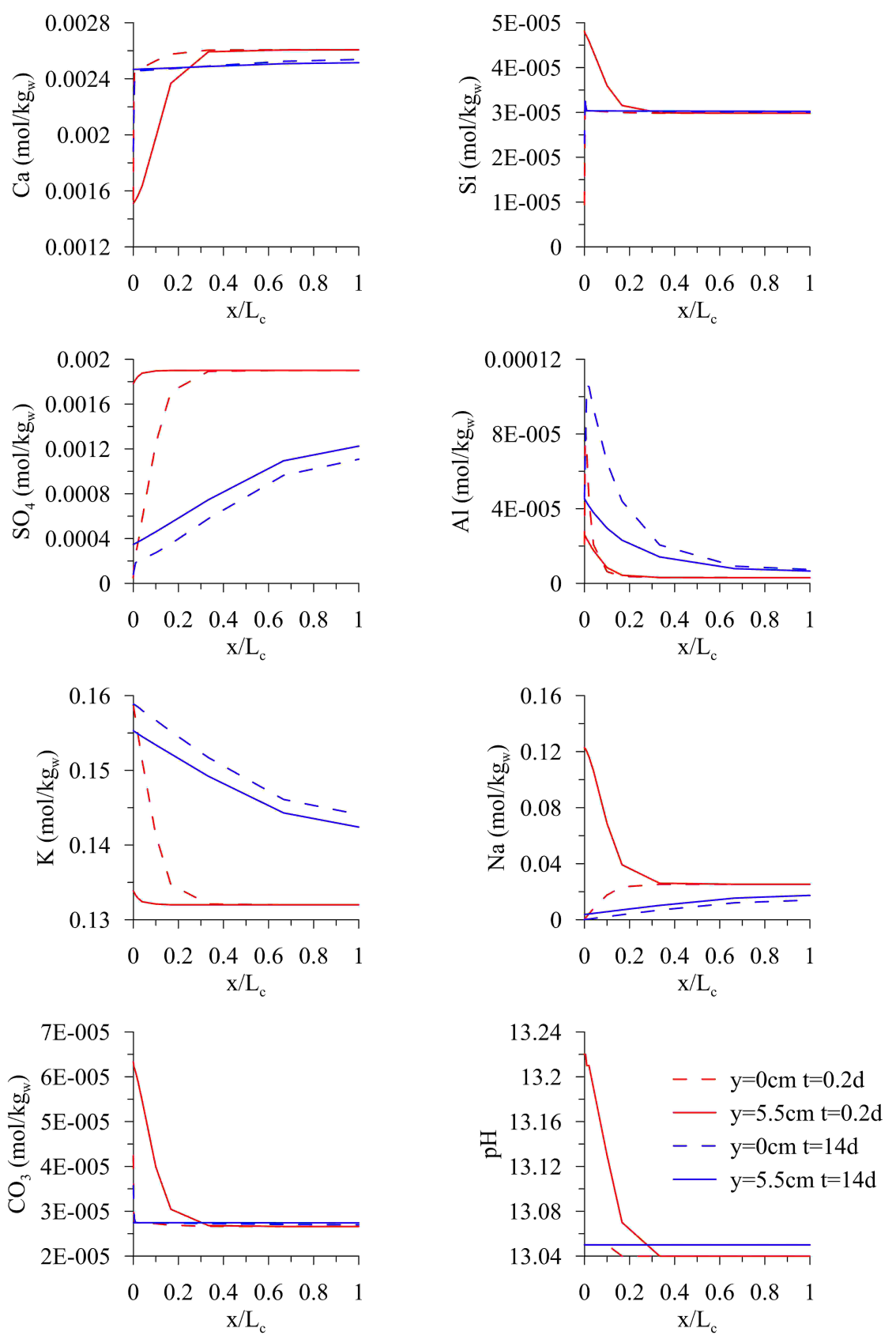

Figure 4: Concentration of each component against dimensionless length (immobile zone), for a $\sigma=8270 \mathrm{~m}^{2} \mathrm{~m}^{-3}$. 

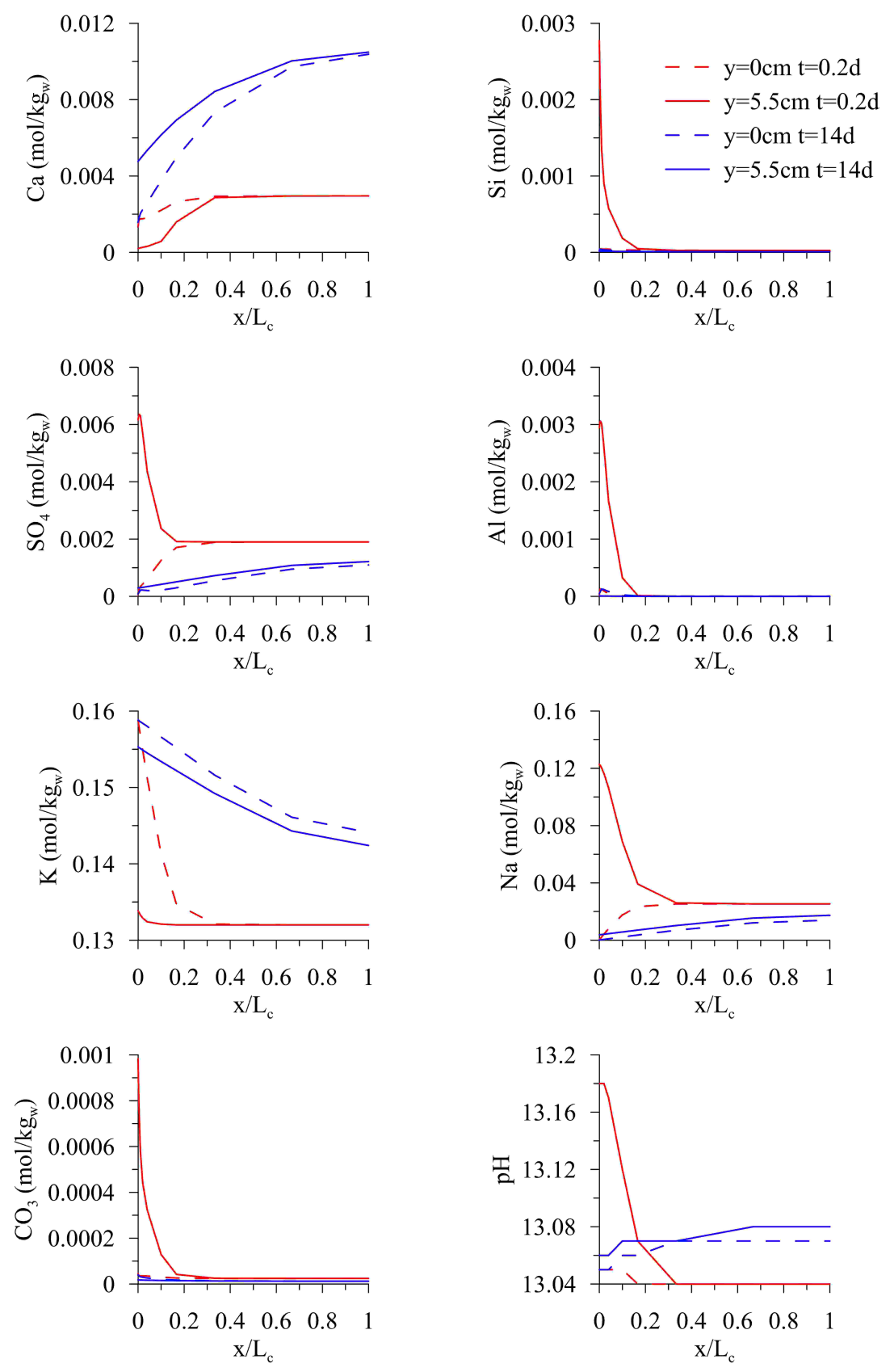

Figure 5: Concentration of each component against dimensionless length (immobile zone), for a $\sigma=0.0827 \mathrm{~m}^{2} \mathrm{~m}^{-3}$. 
of the test (Figure 3). Precipitation of portlandite and calcite is higher for the model with portlandite in equilibrium, giving an almost constant value of Ca controlled by the equilibrium of portlandite. However, when portlandite reaction is controlled by kinetics portlandite precipitates less and more gradually. Although the dissolution of alite and belite is the same in both models, the $\mathrm{Ca}$ from these minerals precipitates as portlandite in the equilibrium model, whereas it remains in solution in the kinetic model. The last fits better the measured data.

\subsection{Porosity}

The variation of porosity in the immobile zone for both models is displayed in Figure 8. Both cases show an increase in porosity due to mineral dissolution in the matrix, being higher, around a factor of 2, when portlandite is considered in equilibrium (large surface area). The minerals that are dissolving are alite, belite, gypsum, ettringite and C-S-H gel. Modelled porosity only changes in the immobile zone, because the surface areas of all minerals in the mobile zone are assumed to be zero. Another conceptual model with minerals in both mobile an immobile zone was also considered, where the initial pore water in the mobile zone was in equilibrium with portlandite. As previously mentioned, the first measured solution composition at the outlet was not at equilibrium with portlandite (first undersaturated and then supersaturated). That numerical model could not fit the experimental data for Ca when there is portlandite in the mobile zone. Hence, we did not consider minerals in the mobile zone, starting with an initial pore water in the mobile zone consistent with the first measured data at the outlet of the sample. Our conceptual model considers advection, dispersion and diffusion in the mobile zone. In the immobile zone there is only diffusion (no flow of water). The conceptual model also assumes that water velocity is uniform across the pore diameter of the mobile zone, whereas in reality it may be larger at the center and smaller near the edges of the pore (Figure 9), giving an interface. According to the model, minerals can only precipitate or dissolve in the immobile zone, so porosity change occurs in the immobile zone, which theoretically does not affect the permeability. Nonetheless, in reality minerals could also precipitate or dissolve in the interface between the mobile and immobile zone. Mineral precipitation in the interface could narrow the pores of the mobile zone, hence reducing the permeability (Figure 9). In our numerical model the interface between the two zones does not change with mineral dissolution-precipitation. Despite this, there is precipitation of 

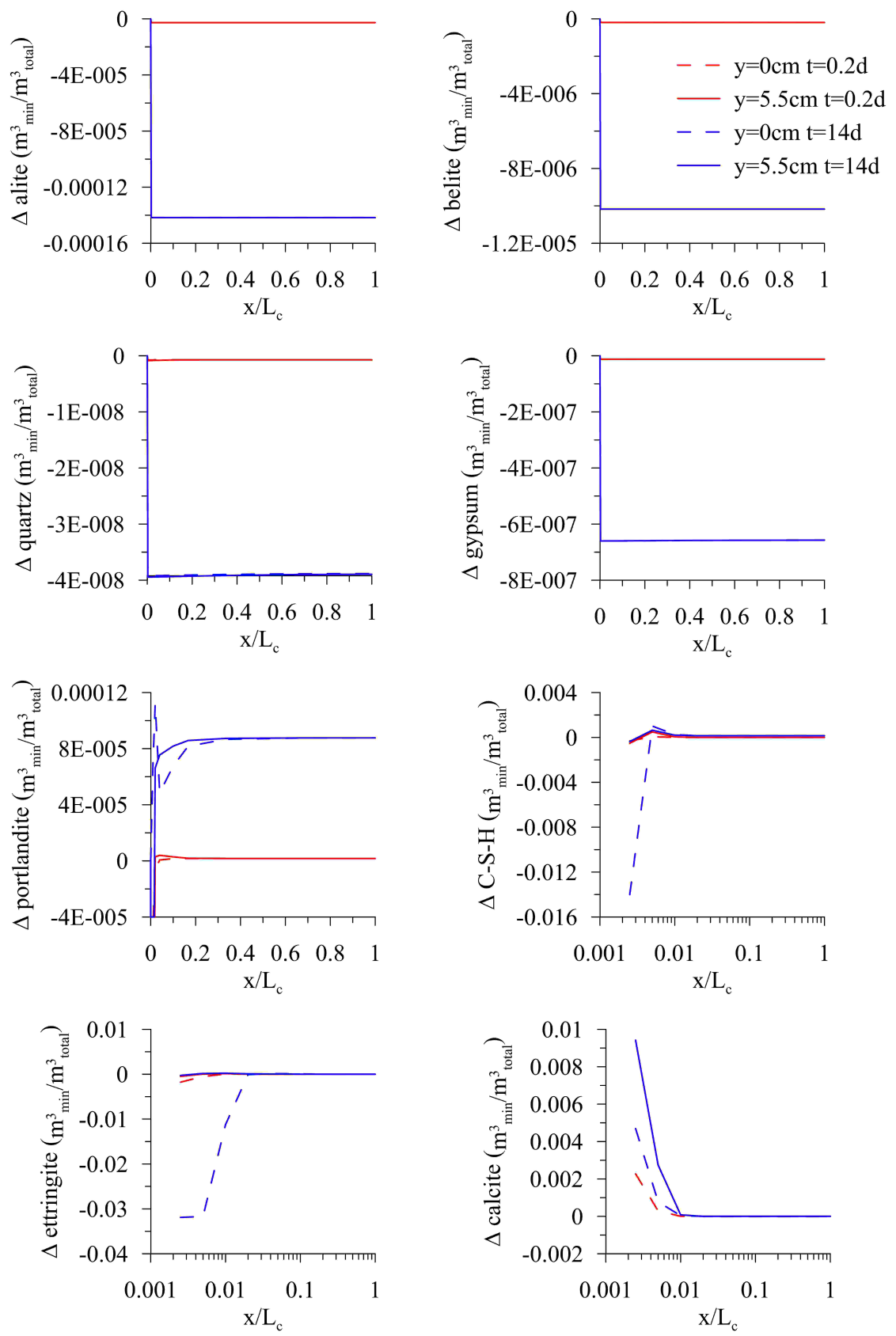

Figure 6: Variation of volumetric fraction of minerals against dimensionless length (immobile zone), for a $\sigma=8270 \mathrm{~m}^{2} \mathrm{~m}^{-3}$. Positive values mean precipitation and negative ones mean dissolution. 

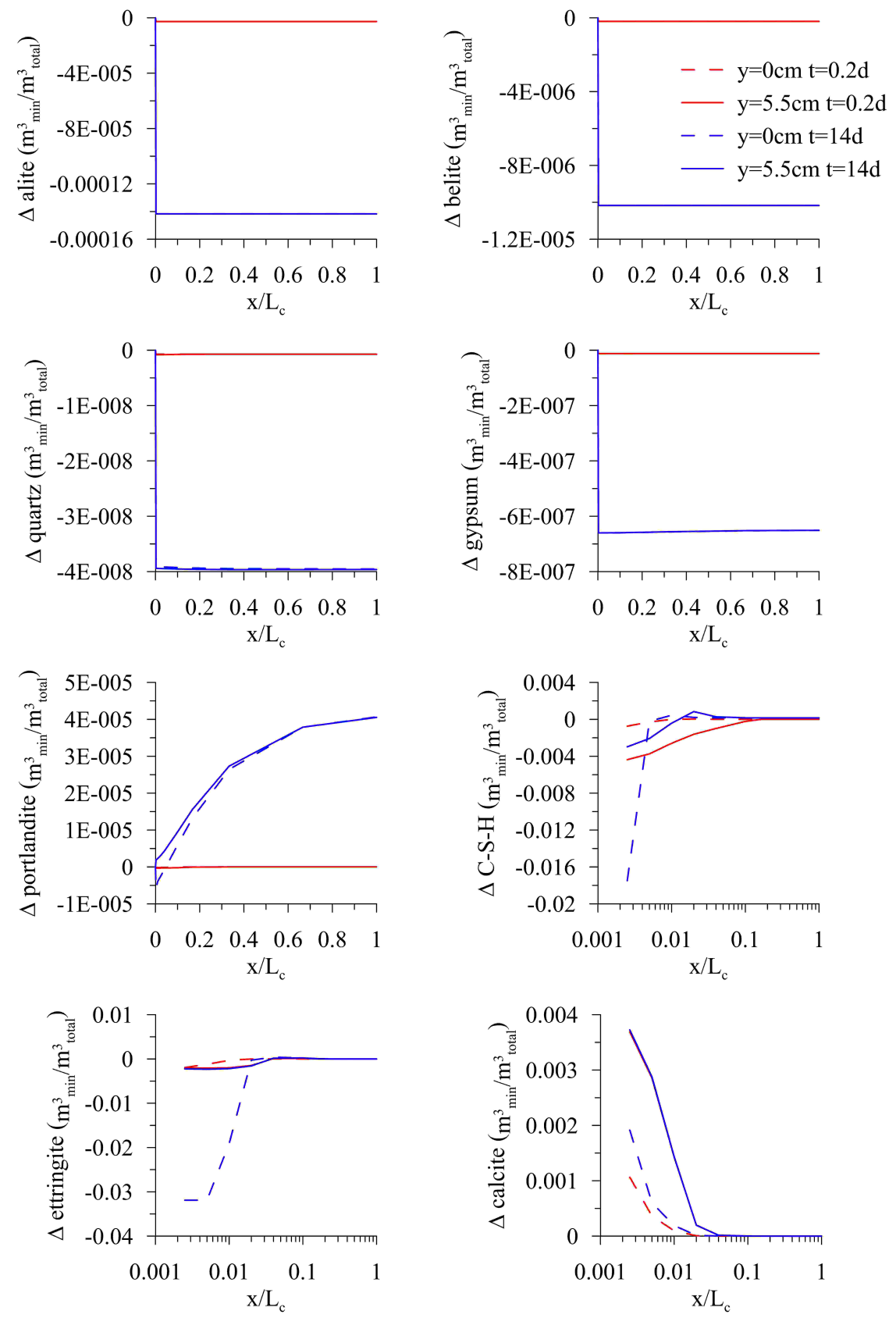

Figure 7: Variation of volumetric fraction of minerals against dimensionless length (immobile zone), for a $\sigma=0.0827 \mathrm{~m}^{2} \mathrm{~m}^{-3}$. Positive values mean precipitation and negative ones mean dissolution. 
calcite and portlandite at the first node of the immobile zone. This mineral precipitation at the contact of the two zones could have reduced the permeability. Detachment of solid particles could also clog parts of the mobile zone, thus reducing permeability. This has already been observed for carbonate materials (Garing et al., 2015).

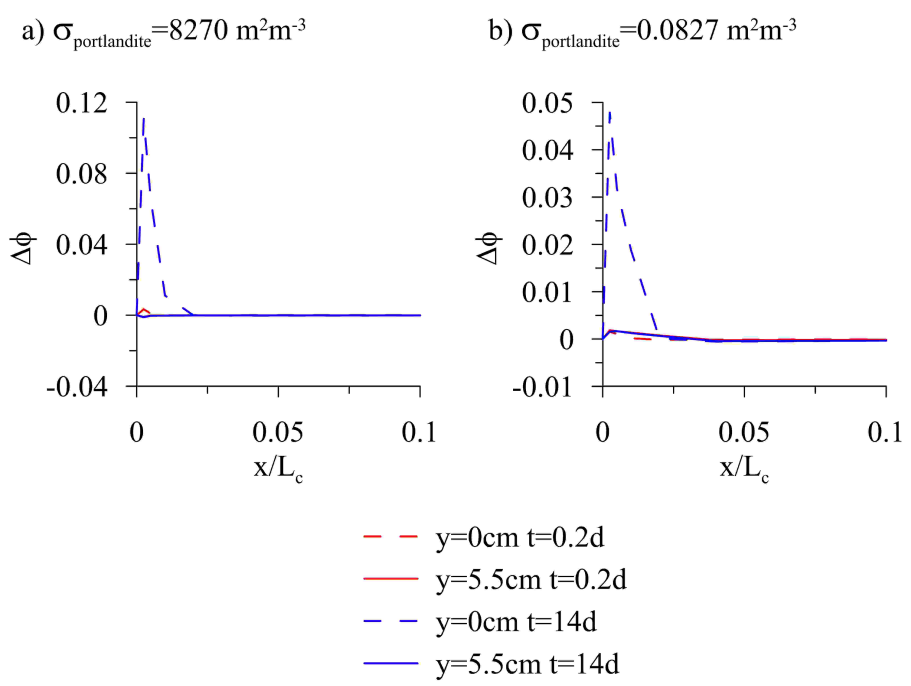

Figure 8: Variation of porosity against dimensionless length (immobile zone).

\section{Conclusions}

Reactive transport models of a high-pH infiltration test in concrete have been developed taking into account matrix diffusion. The model domain consists of a mobile zone representing the well connected pores (with advection, dispersion and diffusion) and an immobile zone representing the matrix (only diffusion). All mineral phases are located in the immobile zone. The cement phases that are taken into account in the numerical model are alite and belite (residual clinker), gypsum, calcite, C-S-H gel, portlandite and ettringite. The aggregates are composed of quartz. The initial pore water in the immobile zone is in equilibrium with the cement phases, but the initial pore water in the mobile zone has been made consistent with the first measured concentrations (early breakthrough). This conceptual model allows a reasonable fit of the model to the experimental data. 


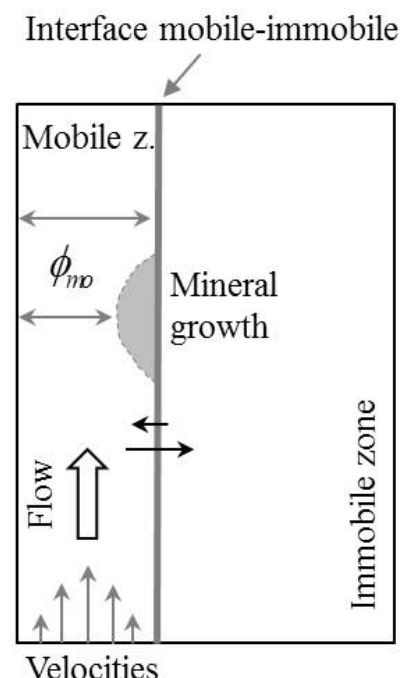

Figure 9: Diagram explaining the possible cause of the reduction of permeability. A variable velocity profile across the mobile zone, together with the available surface area right at the interface, could cause mineral growth on the interface and a narrowing of the mobile zone.

Two different models are compared, one with portlandite in equilibrium (high initial surface area) and another one with portlandite reaction controlled by kinetics (low initial surface area). When portlandite is in equilibrium, modelled $\mathrm{Ca}$ concentrations are practically constant and cannot reproduce the measured data, where $\mathrm{Ca}$ is first undersaturated, and then supersaturated with respect to portlandite. The model with portlandite controlled by kinetics can reproduce this behaviour. The other components are similar for both models obtaining a good fit to the measured data.

The changes in mineralogy calculated for the models show a dissolution of alite, belite, gypsum and quartz. Clinker dissolution causes precipitation of portlandite and C-S-H gel. Near the mobile zone ettringite and C-S-H dissolve due to the lack of $\mathrm{SO}_{4}, \mathrm{Si}$ and $\mathrm{Al}$ in the infiltration water. Calcite precipitates near the mobile zone. When the initial portlandite surface area is higher there is higher precipitation of portlandite and calcite, keeping the Ca concentration constant. But the measured data suggest slower precipitation of portlandite (low surface area).

The assumed conceptual model (minerals only in the immobile zone) does not allow the reproduction of the changes in permeability because the surface 
area and reactivity in the mobile zone are zero. However, the permeability could have decreased due to mineral precipitation (calcite, portlandite) at the contact between the mobile and immobile zones, causing a narrowing of the immobile zone. Nevertheless, particle displacement could also cause the observed decrease in permeability. Inside the immobile zone, both models show an increase in porosity because of mineral dissolution (clinker phases, ettringite and C-S-H).

\section{Acknowledgements}

The authors would like to thank Jordi Illa and Salvador Galí (Universitat de Barcelona) for their help in the X-Ray diffraction analysis. We acknowledge financial support of the Spanish Ministry of Economy and Competitivity through the project HEART (CGL2010-18450), a Research Grant from the Technical University of Catalonia (UPC) and ENRESA (Spanish Nuclear Waste Management Company).

\section{References}

Chaparro, M. C., Saaltink, M. W., 2016. Water, vapour and heat transport in concrete cells for storing radioactive waste. Advances in Water Resources $94,120-130$.

Chaparro, M. C., Saaltink, M. W., Soler, J. M., Slooten, L. J., Mäder, U. K., 2016. Modelling of matrix diffusion in a tracer test in concrete. Transport in Porous Media 111, 27-40.

Chapwanya, M., Stockie, J., Liu, W., 2009. A model for reactive porous transport during re-wetting of hardened concrete. Journal of Engineering Mathematics 65 (1), 53-73.

De Windt, L., Marsal, F., Tinseau, E., Pellegrini, D., 2008. Reactive transport modeling of geochemical interactions at a concrete/argillite interface, Tournemire site (France). Physics and Chemistry of the Earth 33, S295S305.

Garing, C., Gouze, P., Kassab, M., Riva, M., Guadagnini, A., 2015. Anticorrelated porosity-permeability changes during the dissolution of carbonate rocks: Experimental evidences and modeling. Transport in Porous Media 107, 595-621. 
Hummel, W., Berner, U., Curti, E., Pearson, F., Thoenen, T., 2002. Nagra/PSI Chemical Thermodynamic Data Base 01/01. Tech. rep., Universal Publishers/uPUBLISH.com, USA, also published as Nagra Technical Report NTB 02-16, Nagra, Wettingen, Switzerland.

Kosakowski, G., Berner, U., 2013. The evolution of clay rock/cement interfaces in a cementitious repository for low- and intermediate level radioactive waste. Physics and Chemistry of the Earth 64, 65-86.

Kulik, D. c., Kersten, M., 2001. Aqueous Solubility Diagrams for Cementitious Waste Stabilization Systems: II, End-Member Stoichiometries of Ideal Calcium Silicate Hydrate Solid Solutions. Journal of the American Ceramic Society 84, 3017-3026.

Lothenbach, B., Matschei, T., Möschner, G., Glasser, F. P., 2008. Thermodynamic modelling of the effect of temperature on the hydration and porosity of Portland cement. Cement and Concrete Research 38, 1-18.

Parkhurst, D. L., Appelo, C., 1999. User's Guide to PHREEQC (Version 2) - A Computer Program for Speciation, Batch-reaction, One-dimensional Transport, and Inverse Geochemical Calculations. US Geol. Surv. WaterResour. Invest. Rep. 99-4259.

Pfingsten, W., Paris, B., Soler, J., Mäder, U., 2006. Tracer and reactive transport modelling of the interaction between high-pH fluid and fractured rock: Field and laboratory experiments. Journal of Geochemical Exploration 90, 95-113.

Saaltink, M. W., Batlle, F., Ayora, C., Carrera, J., Olivella, S., 2004. RETRASO, a code for modeling reactive transport in saturated and unsaturated porous media. Geologica Acta 2, 235-251.

Savage, D., Soler, J., Yamaguchi, K., Walker, C., Honda, A., Inagaki, M., Watson, C., Wilson, J., Benbow, S., Gaus, I., Rueedi, J., 2011. A comparative study of the modelling of cement hydration and cement-rock laboratory experiments. Applied Geochemistry 26, 1138-1152.

Soler, J., 2012. High-pH plume from low-alkali-cement fracture grouting: Reactive transport modeling and comparison with $\mathrm{pH}$ monitoring at ONKALO (Finland). Applied Geochemistry 27, 2096-2106. 
Soler, J., Vuorio, M., Hautojärvi, A., 2011. Reactive transport modeling of the interaction between water and a cementitious grout in a fractured rock. Application to ONKALO (Finland). Applied Geochemistry 26, 1115-1129.

Soler, J. M., 2013. Reactive transport modeling of concrete-clay interaction during 15 years at the Tournemire Underground Rock Laboratory. European Journal of Mineralogy 25, 639-654.

Soler, J. M., 2016. Two-dimensional reactive transport modeling of the alteration of a fractured limestone by hyperalkaline solutions at Maqarin (Jordan). Applied Geochemistry 66, 162-173.

Trapote-Barreira, A., 2015. Dissolution kinetics of C-S-H gel and durability of mortar. Ph.D. thesis, Universitat Politècnica de Catalunya.

Trapote-Barreira, A., Cama, J., Soler, J., 2014. Dissolution kinetics of C-S-H gel: Flow-through experiments. Physics and Chemistry of the Earth 70-71, $17-31$.

Wolery, T. J., Jackson, K. J., Bourcier, W. L., Bruton, C. J., Viani, B. E., Knauss, K. G., Delany, J. M., 1990. Current Status of the EQ3/6 Software Package for Geochemical Modeling. Chemical Modeling of Aqueous Systems II, 104-116. 